\title{
PENGEMBANGAN SENTRA AGRIBISNIS BAWANG PUTIH DI KECAMATAN SUKAPURA KABUPATEN PROBOLINGGO
}

\author{
Edi Siswadi ${ }^{\# 1}$, Cholyubi Yusuf*2 ${ }^{2}$, Muhammad Zayin Sukri\# ${ }^{3}$, Refa Firgiyanto ${ }^{\# 4}$ \\ ${ }^{\#}$ Jurusan Produksi Pertanian, Politeknik Negeri Jember \\ Jalan Mastrip Kotak Pos 164, Jember \\ ${ }^{\#}$ Jurusan Produksi Pertanian, Politeknik Negeri Jember \\ Jalan Mastrip Kotak Pos 164, Jember \\ ${ }^{1}$ edi_sis_83@yahoo.co.id \\ ${ }^{2}$ yusufcholyubi@gmail.com \\ ${ }^{3}$ mzayinsukri@gmail.com \\ ${ }^{4}$ refa_firgiyanto@polije.ac.id
}

\begin{abstract}
Abstrak
Kabupaten Probolinggo termasuk daerah yang memiliki potensi yang luas untuk ditanami bawang putih dilihat dari peta eksisting dan potensi pengembangan bawang putih nasional. Salah satu kecamatan yang prospek besar untuk dijadikan sebagai sentra agribisnis baru bawang putih adalah kecamatan Sukapura Kabupaten Probolinggo. Salah satu Gapoktan yang telah membudidayakan bawang putih adalah Gapoktan Agro Horti Mandiri yang berasal dari Desa Wonokerta di lereng Gunung Bromo dengan ketinggian tempat $\pm 1.350 \mathrm{~m} \mathrm{dpl}$ dengan jumlah anggota 71 Orang petani. Penerapan sistem sentra agribisnis yang telah berjalan pada kawasan ini tetapi masih belum optimal berdasarkan survey pendahuluan yang telah dilaksanakan oleh tim pengusul antara lain yaitu rendahnya pengetahuan para petani terkait dengan bibit yang berkualitas dan proses pembenihan bawang putih yang didukung oleh tidak adanya penangkar benih dalam jumlah memadai sehingga kebutuhan benih masih bergantung dari pasokan dari luar dengan kualitas yang rendah, belum diterapkannya sistem GAP yang terlihat dari rendahnya kualitas dan kuantitas hasil, rendahnya pengetahuan petani terkait dengan sistem pemasaran pemasaran hasil yang didukung oleh lemahnya sistem kelembagan pertanian. Berkaitan dengan berbagai permasalahan tersebut, Tim pelaksanaan program pengabdian PKM akan memberikan penyuluhan, pelatihan dan pendampingan terkait dengan perbenihan bawang putih, penerapan sistem GAP pada budidaya tanaman bawang putih dan memberikan pelatihan manajemen pemasaran dan keuangan berbasis on line system.

Hasil yang telah dicapai selama kegiatan pengabdian antara lain yaitu tim telah melakukan kegiatan pengabdian mulai dari kegiatan penyuluhan dan pendampingan mengenai program perbenihan dan pembentukan demplot pertanaman bawang putih berdasarkan pada SOP bawang putih yang telah dibuat terlebih dahulu oleh TIM dengan inovasi penerapan teknologi vernalisasi. Selain itu, Tim pengabdian juga telah membuat Wab Gapoktan dengan tujuan agar informasi menganai Gapoktan dapat lebih luas tersebar serta sekaligus dapat membantu dalam proses pemasaran secara online agar terjadi peningkatan kinerja kelompok guna meningkatkan posisi tawar petani dalam mendukung sistem agribisnis pertanian. Pengabdian PKM telah mampu meningkatkan pengetahuan petani dalam penerapan budidaya sesuai GAP dan pemasaran produk yang berkelanjutan dengan kualitas yang lebih baik.
\end{abstract}

Kata Kunci: Bawang putih, berkelanjutan, vernalisasi, website.

\section{PENDAHULUAN}

Bawang putih pada mulanya berasal dari Asia Tengah yaitu Cina dan Jepang yang beriklim subtropik. Penyebaran bawang putih awalnya dibawa oleh pedagang Cina ke Indonesia, kemudian dibudidayakan oleh masyarakat [1]. Manfaat bawang putih bagi tubuh adalah dapat digunakan sebagai pengobatan untuk hipertensi, hiperkolesterolemia, diabetes, rheumatoid arthritis, demam atau sebagai obat pencegahan atherosclerosis dan sebagai penghambat tumbuhnya tumor karena mengandung minyak atsiri, senyawa sulfur sehingga memiliki bau yang kuat, rasa yang khas [2],[3]. Nilai impor komoditas ini terbilang cukup besar pada pada tahun 2016 berkisar 448,881 ribu ton berasal dari China dengan total nilai impor sebesar 448.615.605 US\$ [4]. Nilai Impor yang tinggi ini disebabkan karena peningkatan nilai konsumsi masyarakat umum 
terhadap komoditas ini [5]. Oleh karena itu, untuk mengurangi ketergantungan impor terhadap komoditas ini pemerintah mencanangkan adanya program swasembada bawang putih pada tahun 2021 yang didukung dengan Kebijakan pembangunan pertanian pada 2015-2019 mencakup kebijakan swasembada, pengembangan produk berdaya saing, serta penguatan sistem dan kelembagaan. Kegiatan ini diharapakan akan dapat mengulang kejayaan swasembada bawang putih seperti pada tahun 1990-an sampai dengan tahun 1998 [6]. Salah satu kebijakan yang adalah dengan adanya pengembangan kawasan sentra bawang putih bagi importir untuk melakukan penanaman 5\% dari volume impor yang diajukan berdasarkan Permentan No. 16 Tahun 2016 dan No. 38 Tahun 2017 Tentang Rekomendasi Produk Impor Hortikultura (RIPH).

Kabupaten Probolinggo termasuk daerah yang memiliki potensi tanam bawang putih dilihat dari peta eksisting dan potensi pengembangan bawang putih nasional. Luas maksimum yang pernah dicapai diwilayah ini dalam kurun waktu (1993-2015) adalah seluas $603 \mathrm{Ha}$. Luas area tanam Bawang Putih pada tahun 2018 di Probolinggo mencapai 49 Ha dengan rata-rata produksi 12 ton/ha. Kecamatan Sukapura Kabupaten Probolinggo merupakan salah satu kawasan baru pengembangan bawang putih. Luas tanam pada area ini mencapai $10 \mathrm{Ha}$ dan pada tahun 2018 kawasan ini telah melaksanakan panen perdana jumlah produksi 40 ton pada luasan wilayah $2 \mathrm{Ha}$. Salah satu Gapoktan yang telah membudidayakan bawang putih adalah Gapoktan Agro Horti Mandiri Gapoktan Agro Horti telah membudidayakan bawng putih sejak 2017. Bibit bawang putih yang digunakan oleh petani berasal dari wilayah Tawanagmangu Jawa Tengah yaitu Varietas Lumbu Kuning dan Lumbu Hijau yang merupakan varietas lokal Indonesia. Penerapan sistem sentra agribisnis yang telah berjalan pada kawasan ini masih belum optimal berdasarkan survey pendahuluan yang telah dilaksanakan oleh tim pengusul diantaranya rendahnya pengetahuan para petani terkait dengan bibit yang berkualitas dan proses pembenihan bawang putih, Belum adanya petani penangkar benih bawang putih yang berasal dari gabungan kelompok tani dalam jumlah yang memadai, Budidaya bawang putih yang dilakukan oleh para petani masih kurang optimal karena belum menerapkan sistem GAP, terbatasnya pengetahuan petani mengenai sistem pemasaran berbasiskan online. Permasalahan tersebut menjadikan alasan mendasar terkait dengan pelaksanaan kegiatan pengabdian kepada masyarakat diwilayah tersebut. Adanya kegiatan pendampingan diharapkan akan dapat membantu dalam pengembangan sentra agribisnis baru di Probolinggo yang mandiri dalam sistem perbenihan dengan kualitas produksi optimal yang didukung oleh kelembagaan petani yang kuat dan sistem manajemen pemasaran yang baik sehingga akan mampu mendukung program Pemerintah terkait dengan Swasembada Bawang Putih secara Nasional pada tahun 2021.

\section{TARGET DAN LUARAN}

Sasaran pengabdian PKM adalah petani di Gapoktan Agro Horti Mandiri. Pengabdian masyarakat tersebut dilakukan dengan adanya pertimbangan bahwa pengembangan sentra agribisnis bawang putih menjadi aspek penting dalam mendukung program pemerintah dan peningkatan kualitas hasil budidaya. Luaran yang didapatkan adalah peningkatan pengetahuan dan ketrampilan petani terkait dengan perbenihan, dan penerapan budidaya bawang putih sesuai dengan GAP yang telah tersusun dalam bentuk modul. Selain itu, luaran dari kegiatan ini yaitu diterapakannya sistem pemasaran yang baik misalnya melalui packgaing dan labeling produk, penjualan secara on line dan penjualan secara langsung sebagai oleh-oleh.

\section{METODE PELAKSANAAN}

\section{A. Waktu dan Tempat}

Kegiatan pengabdian dengan judul "PKM Pengembangan Sentra Agribisnis Bawang Putih di Kecamatan Sukapura Kabupaten Probolinggo" ilaksanakan selama delapan bulan pada tahun $2019 \mathrm{Di}$ Desa Wonokerto Kecamatan Sukapura Kabupaten Probolinggo.

\section{B. Tim Pelaksana Kegiatan}

Pihak yang terlibat dalam pelaksanan program pengabdian ini adalah Dosen, Teknisi, mahasiswa, Gapoktan Agro Horti Mandiri, penyuluh pertanian setempat dan masyarakat umum.

C. Tahapan penerapan pelatihan

1. Analisis Kebutuhan masyarakat

Analisis kebutuhan dilakukan dengan cara survey ke tempat calon mitra, kemudian melakukan diskusi dan pembuatan FGD (Focus group discussion) dengan 
kelompok tani, perwakilan perangkat desa dan penyuluh setempat untuk mengetahui permasalahan-permasalahan yang ditemukan terkait dengan budidaya bawang putih yang sudah dilakukan oleh masyrakat dan sistem pemasarannya.

\section{Penyuluhan dan Praktek}

Kegiatan penyuluhan dilakukan di rumah salah satu anggota Gapoktan Agro Horti Mandiri. Penyuluhan dilaksanakan melalui pertemuan secara langsung dan dilanjutkan dengan FGD agar terjadi perubahan perilaku untuk bertani lebih baik (better farming), berusahatani lebih menguntungkan (better bussines), hidup lebih sejahtera (better living), dan bermasyarakat lebih baik (better community) melalui penerapan inovasi teknologi baru. Materi yang diberikan dalam penyuluhan dan praktek meliputi:

a. Perbenihan dan proses sertifikasi benih bawang putih

Ketersediaan benih dalam jumlah yang memadai dan berkelanjutan serta terjamin kualitasnya akan berdampak pada peningkatan minat masyarakat untuk dapat menanam bawang putih dalam jumlah yang besar [7], [8]. SOP perbenihan bawang putih mengikuti Peraturan Mentri Pertanian tahun 2006, pelaksanaan teknis sertifikasi benih hortikultura [9] yang dikeluarkan oleh Dirjen Hortikultura dan SOP produksi benih bawang putih yang dikeluarkan oleh Dirjen Hortikultura [10]. Produksi bawang putih yang sudah dihasilkan untuk perbenihan kemudian akan dilakukan proses sertifkasi. Penyuluhan dan pelatihan juga dilanjutkan dengan pengenalan penerapan Vernalisasi kepada mitra dalam memecah dormansi benih. Perlakuan ini sedang diteliti lebih mendalam oleh tim Peneliti dari Politeknik Negeri Jember, dengan hasil sementara perlakuan vernalisasi pada suhu 4-100 C selama delapan minggu dapat mempercepat munculnya perkecambahan tunas dari umbi. Hasil tersebut juga didukung oleh penelitian Kim et al. [11] dan $\mathrm{Wu}$ et al. [12]. Perlakuan vernalisasi akan meningkatkan aktivitas pembelahan sel dan giberelin endogen serta peningkatan auksin sehingga dapat mempercepat proses pembelahan sel [13], [14], [15]. Aplikasi penerapan teknologi ini diharapkan akan mampu membantu ketersedian umbi bawang putih secara berkelanjutan guna mendukung perkembangan agribisnis bawang putih di Kabupaten Probolinggo.

b. Penyuluhan dan praktek serta asistensi penerapan sistem budidaya bawang putih sesuai dengan GAP dan GHP

Penyuluhan dan praktek serta asistensi penerapan sistem budiaya bawang putih pada mitra terkait prinsi Good Agricultural Practices (GAP) mencakup penerapan teknologi yang ramah lingkungan, penjagaan kesehatan dan peningkatan kesejahteraan pekerja, Praktek kegiatan GAP dilakukan melalui tahapan pemilihan lokasi, penentuan waktu tanam, penyiapan benih, persiapan lahan, penanaman, pemeliharaan tanaman, pencegahan penularan Organisme Pengganggu Tanaman (OPT) dan penanganan panen serta pasca panen.

c. Pelatihan sistem pemasaran bawang putih untuk perbenihan dan konsumsi

Tim PKM akan memberikan pelatihaan manajemen pemasaran. Selain itu, tim PKM akan membekali mitra terkait dengan pelatihan manajemen keungan agar semua arus keungan dapat diatur dengan baik dan sistem penjualan berbasis on line terutama karena kebutuhan akan bawang putih akan terus meningkat setiap tahunnya.

\section{HASIL DAN PEMBAHASAN}

Kegiatan PKM (program kemitraan masyarakat) sumberdana DRPM dengan judul "Pengembangan Sentra Agribisnis Bawang Putih Di Kecamatan Sukapura Kabupaten Probolinggo" diawali dengan kegiatan survei terlebih dahulu. Kegiatan survei dilakukan pada bulan April 2019. Adapun tujuan dari kegiatan ini adalah untuk mengetahui kondisi mitra yang terbaru dengan memperhitungkan analaisis situasi dan kebutuhan. Hasil survei kemudian dijadikan acuan dalam pelaksanaan pengabdian yang akan dilaksanakan. Beberapa hasil survei antara lain yaitu adanya pertanaman bawang putih yang tumbuh kurang optimal karena kurangnnya penerapan GAP, sistem pengairan untuk pemeliharaan masih belum berjalan secara optimal dan pemakaian benih masih bergantung pada benih dari luar pada umumnya karena benih hasil produksi Gapoktan masih sangat terbatas (Gambar 1). 


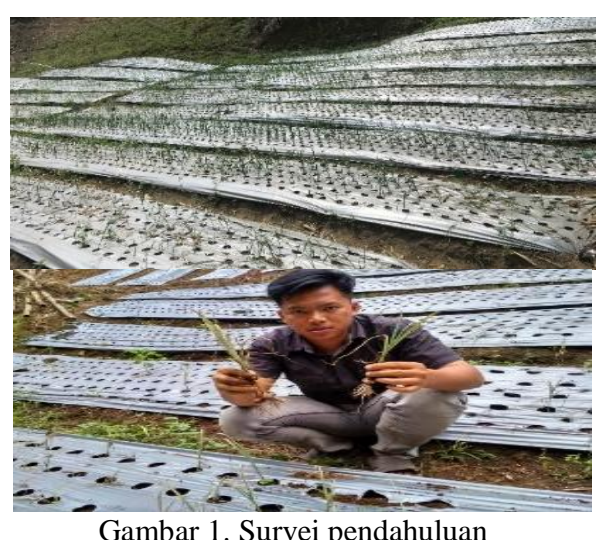

Gambar 1. Survei pendahuluan

Benih bawang putih yang sudah digunakan sebelumnya oleh Petani diwilayah sekitar mitra kemudian diinventarisir terutama untuk benih-benih yang sudah tersertifikasi. Tujuannya adalah untuk dijadikan sebagai benih awal untuk perbanyakan benih bagi para petani melalui skema penanaman pada lahan demplot. Benih yang dipilih harus bermutu yaitu bebas hama dan penyakit, pangkal batang berisi penuh dan keras, siung bernas, besar siung untuk bibit 1,5 sampai 3 gram. Benih bawang putih yang sudah terpilih kemudian diperlakukan dengan teknologi vernalisasi. Vernalisasi dilakukan dengan menyimpan benih bawang putih pada suhu 4-100 C selama empat minggu minggu guna mempercepat munculnya perkecambahan tunas dari umbi (Gambar 2). Benih hasil vernalisasi nantinya akan diseleksi kembai untuk mengetahui benih-benih yang bermutu baik.

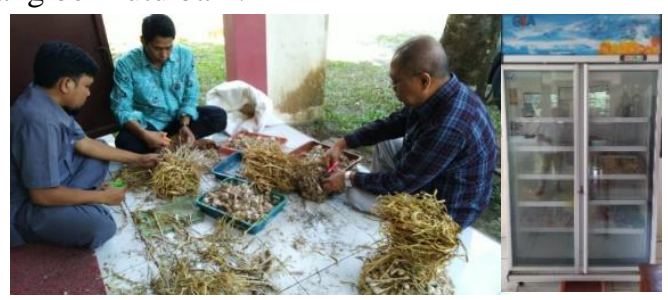

Gambar 2. Tahap vernalisasi

Kegiatan pengabdian dilanjutkan dengan pembelian perlengkapan bahan untuk pembuatan demplot budidaya bawang putih sesuai dengan GAP dilahan dekat dengan lokasi mitra guna perbanyakan benih dan dilanjutkan dengan kegiatan koordinasi awal sebelum penyuluhan dan pelatihan serta pembuatan demplot. Kegiatan ini merupakan bagian awal dari rangkain tindak lanjut hasil survei yang dilakukan sebelumnya. Berdasararkan hasil analisis situasi dan kebutuhan, tim pertama kali melakukan kegiatan. Penyuluhan dilaksanakan melalui pertemuan secara langsung dan dilanjutkan dengan FGD. Penyuluhan dilakukan di salah satu rumah pengurus kelompok tani, dengan dihadiri oleh petani mitra, PPL Dinas Pertanian, mahasiswa dan juga tim pengabdian. Materi penyuluhan tahap pertama terdiri atas dua tema pokok yaitu berkaitan dengan proses berbenihan dan tahapan sertifikasinya yang dibawakan oleh Ir. M. Zayin Sukri serta sistem sistem budidaya bawang putih yang sesuai dengan GAP yang disampaikan oleh Dr. Edi Siswadi. Luaran yang diperoleh dari kegiatan ini adalah meningkatknya pengetahun dan ketrampilan petani mitra terkait dengan dua tema tersebut sehingga hasil produksi dari lahan para petani mitra dapat optimal dari segi kualitas dan kuantitas. Guna mempermudah dalam proses transfer pengetahuan, materi penyuluhan juga telah dibagikan dalam bentuk modul (Gambar 3).

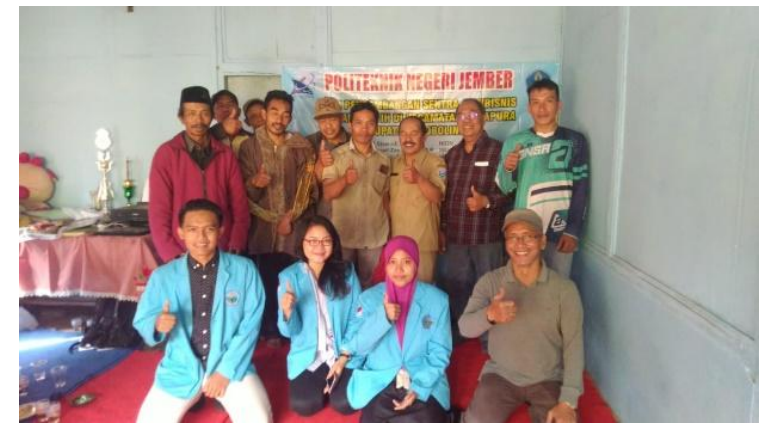

Gambar 3. Penyuluhan dan pelatihan proses sertifikasi benih dan penerapan budidaya sesuai GAP dan GHP

Lahan demplot yang sudah disetujui selanjutnya dilakukan proses budidaya sesuai dengan SOP yang telah disusun oleh Tim sebelumnya. Tahap awal dilakukan pengolahan tanah kemudian dibuat bedengan dengan lebar 1 meter, tinggi $40 \mathrm{~cm}$ dan jarak antar bedengan 1 meter (Gambar 4). Bedengan yang telah terbentuk kemudian ditaburkan dengan kapur agar pH menjadi netral dan diberi pupuk dasar berupa pupuk kandang dan NPK kemudian ditutup dengan plastik hitam agar gulma tidak tumbuh dan kelembaban tanah tetap terjaga (Gambar 5).
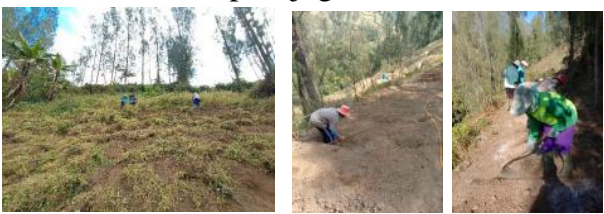

Gambar 4. Proses pengolahan tanah

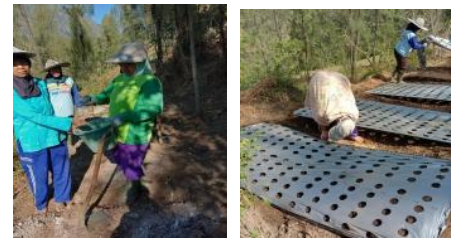

Gambar 5. Pemberian pupuk dasar dan pemberian mulsa plastik 
Pada tahapan ini juga dilakukan perbaikan instalansi air yang sudah ada, tujuannya adalah agar proses penyiraman dapat dilakukan dengan lebih muda. Salah satu kendala dalam budidaya bawang putih pada musim kemarau adalah ketersedian air diwilayah bromo. Bentuk perbaikan dari instalansi ini yaitu pembuatan penampungan air dengan bantuan mesin diesel air yang diperoleh dari sungai yang letaknya jauh dari lahan demplot kemudian ditampang dalam bak terpal (Gambar 6).
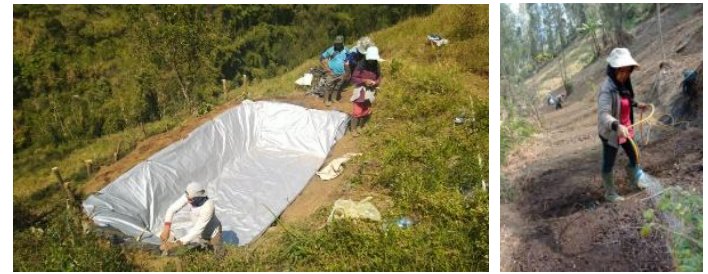

Gambar 6. Perbaikan instalansi air

Lahan yang telah siap kemudian ditanam dengan bawang putih yang telah melewati proses vernalisasi. Benih terlebih dahulu disortasi kembali dan diberi fungisida. Penanaman dilakukan dengan memasukan langsung umbi bawang putih ketanah dengan cara ditugal kemudian setelah selesai ditutup kembali dengan tanah. Benih yang telah ditanam kemudian dipelihara dengan mengacu pada SOP yang telah diberikan sampai dengan panen dan penanganan pasca panen (Gambar 7).
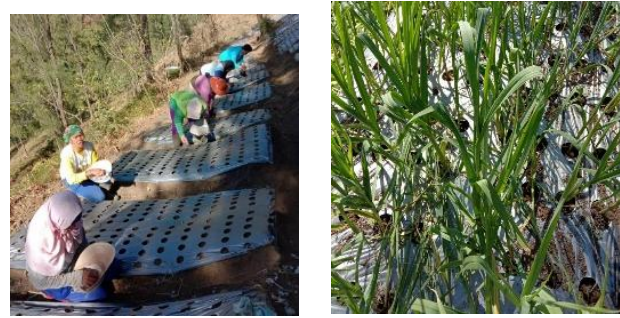

Gambar 7. Proses penanaman dan pertanaman bawang putih pada umur 3 bulan setelah tanam

Kegiatan pengabdian kemudian dilanjutkan dengan perbaikan gudang pasca panen yang dilakukan meliputi perbaikan rak dan sanitasi dalam gudang. Hal tersebut disebabkan karena hasil panen bawang putih apabila setelah dipanen tidak ditangani dengan baik, akan mengalami perubahan akibat pengaruh fisiologis, fisik, kimiawi, parasitik atau mikrobiologis. Pengaruh yang timbul dapat bersifat menguntungkan apabila mampu mengendalikannya, sedangkan apabila tidak dikendalikan menyebabkan kerusakan atau kebusukan pada hasil produksi. Kerusakan ini akan dapat menurunkan kualitas dan kuantitas hasil panenan (kehilangan hasil). Perbaikan dalam gudang dilakukan juga agar benih yang dihasilkan dapat memiliki mutu yang baik untuk proses budidaya selanjutnya (Gambar 8 dan 9).

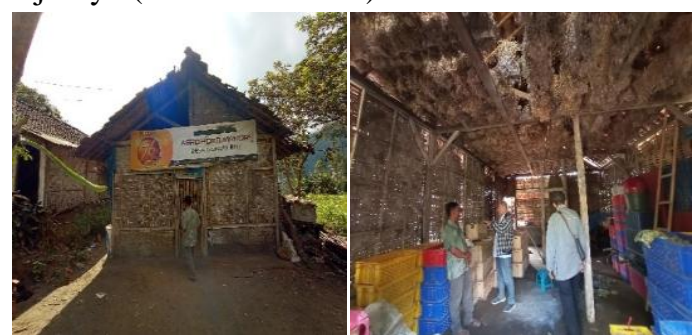

Gambar 8. Gudang pasca panen sebelum perbaikan
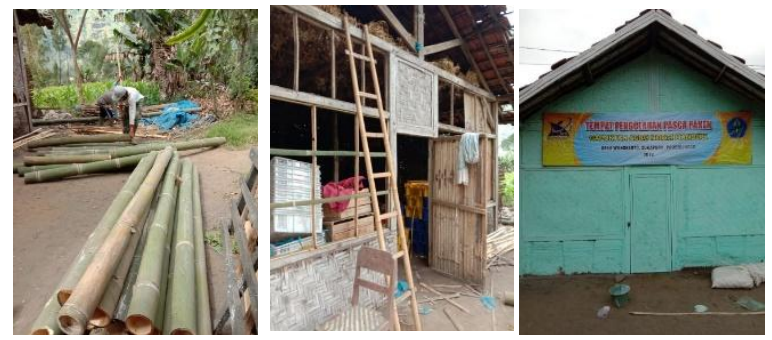

Gambar 9. Proses perbaikan dalam gudang pasca panen untuk rak dan sanitasi

Kegiatan perbaikan manajemen pada mitra meliputi pelatihan dan pendampingan pengemasan, pembukuan dan pemasaran. Kegiatan pengemasan dilakukan dengan pemberian branding produk dengan tujuan agar produk memiliki nilai tawar yang lebih tinggi. Sedangkan, perbaikan untuk pembukuan mitra dilatih pembukuan arus khas, buku pembelian, buku penjualan, dan buku persedian agar selalu aktivitas dalam Gapoktan dapat terdata dengan baik dan tidak tercampur dengan kepentingan masing-masing. Pembukuan tersebut dapat menjadi acuan bagi Gapoktan dalam proses monitoring dan evaluasi proses produksi dan keuangan Gapoktan. Pendampingan pemasaran kemudian dilanjutkan dengan pelatihan pengoperasional wabsite Gapoktan (http://agrohortimandiri.com) agar proses pemasaran menjadi lebih luas (Gambar 10).

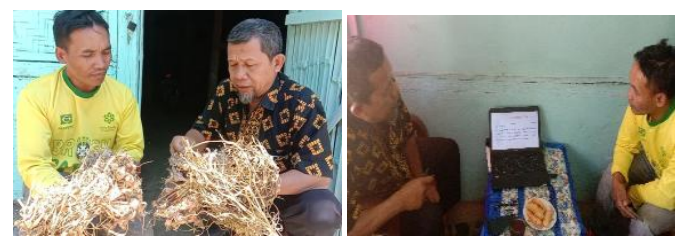

Gambar 10. Pendampingan manajemen pemasaran

\section{KESIMPULAN}

Luaran yang telah tercapai dari kegiatan pengabdian sampai pada saat ini yaitu meningkatnya pengetahuan dan ketrampilan mitra terkait dengan proses perbenihan dan sertifikasinya serta penerapan budidaya bawang putih sesuai dengan GAP. Selain itu, 
pembuatan demplot juga dapat dijadikan acuan bagi petani untuk dapat menerapakan teknologi GAP pada musim yang akan datang sehingga dapat meningkatkan produksi dari bawang putih. Perbaikan manajemen pemasaran juga sudah mulai terlihat dengan dibuatnya buku keungan dan branding produk untuk tujuan konsumsi dan benih serta pembuatan wabsite gapoktan yang dikelola secara berkelanjutan.

\section{UCAPAN TERIMAKASIH}

Pengabdian kegiatan PKM dilaksanakan dengan sumberdana dari Direktorat Riset dan Pengabdian Masyarakat Direktorat Jenderal Penguatan Riset dan Pengembangan, Kementerian Riset, Teknologi, dan Pendidikan Tinggi sesuai dengan Perjanjian Pendanaan Pelaksanaan Program Pengabdian Masyarakat Nomer : 0890/PL17.4/PM/2019, tanggal 28 Mei 2019

\section{DAFTAR PUSTAKA}

[1] Syamsiah, I.S., dan Tajudin. 2003. Khasiat dan Manfaat Bawang Putih. Jakarta: Agromedia Pustaka.

[2] Majewski M. 2014. Allium sativum: Facts and Myths Regarding Human Health. J Natl Ins Public Health. 65 (1): 1-8.

[3] Shiferaw G.D. 2016. Review of Management Strategies of Constraints in Garlic (Allium sativum L.) Production. The J. of Agri. Sci. 11( 3): Pp 186207.

[4] Direktorat Jendral Hortikultura. 2017. Pengembangan Bawang Putih. Kementrian Pertanian. Jakarta

[5] Sarwadana S.M., Gunadi I.G.A. 2007. Potensi Pengembangan Bawang Putih (Allium Sativum L.) Dataran Rendah Varietas Lokal Sanur. J. Agritrop, 26 (1) : 19 - 23 (2007)

[6] Julianto PA dan Ika A. 2017. Harga Bawang Putih yang Mengagetkan. https://ekonomi.kompas.com/read/2017/05/26/082 045326/harga.bawang.putih.yang.mengagetkan (Diakses tanggal 14 Maret 2018).

[7] Nagasawa A, Finer J. 1988. Development of morphogenic suspension culture of garlic (Allium sativum L.). Plant Cell Tissue Organ Cult 15:183187.

[8] Barandariaran X, Martin N, Rodriguez M, Di Pietro A, Martin J. 1999. Genetic variability in the calogenesis and regeneration of garlic. Plant Cell Rep. 18:434-437.
[9] Direktorat Jendral Hortikultura. 2016. Teknis Sertifikasi Benih Hortikultura. Kementrian Pertanian. Jakarta.

[10] Direktorat Jendral Hortikultura. 2016. SOP Perbenihan Bawang Putih. Kementerian Pertanian Jakarta.

[11] Kim E.K., E.J. Hahn, H.N. Murthy, K.Y. Paek. 2003. High frequency of shoot multiplication and bulblet formation of garlic in liquid cultures. Plant e Tiss. Org. Cult. 73:231-236.

[12] Wu C, Wang M., Dong Y., Meng H. 2015 Growth, bolting and yield of garlic (Allium sativum L.) in response to clove chilling treatment. Scientia Horticulturae 194:43-52

[13] Jain R., A.K. Shrivastava, S. Solomon, R.L. Yadav. 2007. Low temperature stress-induced biochemical changes affect stubble bud sprouting in sugarcane (Saccharum spp. hybrid). Plant Growth Regul. 53:17-23.

[14] Dinarti D., B.S. Purwoko, A. Purwito, dan A.D. Susila. 2011. Perbanyakan tunas mikro pada beberapa umur simpan umbi dan pembentukan umbi mikro bawang merah pada dua suhu ruang kultur. Jurnal. Agron. Indonesia 39: 97 - 102

[15] Jasmi Sulistyaningsih E., Indradewa D. 2013. Pengaruh vernalisasi umbi terhadap pertumbuhan, hasil, dan pembungaan bawang merah (Allium cepa L. aggregatum group) di dataran rendah. J. Ilmu Pertanian 16 (1): 42 